U. S. DEPARTMENT OF COMMERCE

JESSE H. JONES, Secretary

NATIONAL BUREAU OF STANDARDS

LYMAN J. BRIGGS, Director

\title{
MINERAL WOOL: BLANKETS, BLOCKS, INSULATING CEMENT, AND PIPE INSULATION FOR HEATED INDUSTRIAL EQUIPMENT
}

\section{COMMERCIAL STANDARD CS117-44}

Effective Date for New Production From May 25, 1944

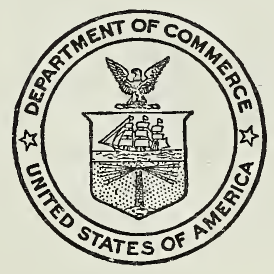

\section{A RECORDED VOLUNTARY STANDARD} OF THE TRADE

\author{
UNITED STATES
}

GOVERNMENT PRINTING OFFICE

WASHINGTON : 1944 


\section{$P R O M U L G A T I O N$}

of

COMMERCIAL STANDARD CS117-44

for

MINERAL WOOL: BLANKETS, BLOCKS, INSULATING CEMENT, AND PIPE INSULATION FOR HEATED INDUSTRIAL EQUIPMENT

On November 1, 1943, at the instance of the Industrial Mineral Wool Institute, a proposed commercial standard for mineral wool; blankets, blocks, insulating cement, and pipe insulation for heated industrial equipment was circulated to leading distributors, user organizations, Government agencies and to manufacturers for comment. Following adjustment in the light of the comment, the recommended commercial standard was circulated on January 7, 1944, to the entire trade for written acceptance.

Those concerned have since accepted and approved the standard as shown herein for promulgation by the U. S. Department of Commerce, through the National Bureau of Standards.

The standard is effective for new production from May 25, 1944.

Promulgation recommended.

Promulgated.

I. J. Fairchild, Chief, Division of Trade Standards.

Promulgation approved.

Lyman J. Briggs, Director, National Bureau of Standards.

Jesse H. Jones, Secretary of Commerce.

II 


\section{MINERAL WOOL: BLANKETS, BLOCKS, INSULATING CEMENT, AND PIPE INSULATION FOR HEATED INDUSTRIAL EQUIPMENT}

\section{COMMERCIAL STANDARD CS117-44}

\section{CONTENTS}

Page

Promulgation

Purpose

Scope

General requirements

Detail requirements:

Blanket insulation

Block insulation 3

Insulating cement.... 3

Pipe insulation:

Blanket type._.

Molded type

Recommended installation requirements:

Auxiliary material

Application (general)

Blanket insulation

Block insulation

Insulating cement (built-up applications)

Blanket-type pipe insulation

Molded-type pipe insulation

Guides for painting

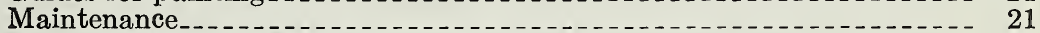

Guarantee labels and certificates.

Effective date

Standing committee....... 23

History of project

Acceptance of Commercial Standard

To the Acceptor

Acceptors

\section{PURPOSE}

1. The purpose of this standard is (a) to establish minimum specifications for insulating heated surfaces with mineral wool products, for the guidance of manufacturers, distributors, installers, contractors, engineers and users, (b) to avoid delays and misunderstandings, and (c) to provide a standard basis for certifying quality of material and installation.

\section{SCOPE}

2. This standard provides minimum requirements for mineral wool blankets, blocks, insulating cement, and pipe insulation for insulating heated industrial equipment. It covers requirements for material, thermal conductivity, density, standard sizes and tolerances. The standard also lists the recommended minimum insulation thickness required for various operating temperatures and recommended methods of product installation. The range of types, conductivities, classes, temperature limits, and sizes of mineral-wool products for insulating heated industrial equipment are shown in table 1: 
TABLE 1.-Types, conductivities, classes and sizes of mineral wool products

\begin{tabular}{|c|c|c|c|c|c|c|}
\hline \multirow{2}{*}{ Types } & \multicolumn{3}{|c|}{$\begin{array}{l}k \text { at }{ }^{\circ} \mathrm{F} \text { mean } \\
\text { temperature }\end{array}$} & \multicolumn{2}{|c|}{$\begin{array}{l}\text { Maximum } \\
\text { temperature } \\
\text { limit }\end{array}$} & \multirow{2}{*}{ Sizes } \\
\hline & 200 & 300 & 400 & Class & ${ }^{\circ} \mathrm{F}$ & \\
\hline Blanket.. & 0.41 & 0.47 & 0.53 & $\left\{\begin{array}{l}B \ldots \\
C\end{array}\right.$ & $\begin{array}{l}1,000 \\
1,200\end{array}$ & $\begin{array}{l}1 \text { to } 6 \text { in. thick by } 24 \text { in. wide by } 48 \text { in. } \\
\text { or } 96 \text { in. long. }\end{array}$ \\
\hline Blocks & 0.50 & 0.53 & 0.56 & $\left\{\begin{array}{l}A \\
C-\cdots \\
D_{-}-\cdots\end{array}\right.$ & $\begin{array}{r}600 \\
1,200 \\
1,600\end{array}$ & $\begin{array}{l}1 \text { to } 4 \text { in. thick by } 6 \text { in. or } 12 \text { in. wide } \\
\text { by } 18 \text { in. or } 36 \text { in. long. }\end{array}$ \\
\hline Cement.... & 0.70 & 0.75 & 0.80 & $\left\{\begin{array}{l}C-\cdots \\
E_{-}-\cdots\end{array}\right.$ & $\begin{array}{l}1,200 \\
1,800\end{array}$ & \}Packaged in 50-1b. bags. \\
\hline Pipe insulation (blanket-type) - & 0.41 & 0.47 & 0.53 & $\left\{\begin{array}{l}B \\
C_{-}\end{array}\right.$ & $\begin{array}{l}1,000 \\
1,200\end{array}$ & $\begin{array}{l}1 \text { to } 4 \text { in. thick by } 24 \text { in. long fabri- } \\
\text { cated to fit } 2 \text { in. and larger pipe. }\end{array}$ \\
\hline Pipe insulation (molded-type) & 0.42 & 0.46 & 0.50 & $\left\{\begin{array}{l}A \\
A \\
C\end{array}\right]$ & $\begin{array}{r}600 \\
1,200\end{array}$ & $\begin{array}{l}7 / 8 \text { to } 4 \text { in. thick by } 36 \text { in. long to fit } \\
\text { 1/2 to } 12 \text { in. and larger steel pipe } \\
\text { sizes. }\end{array}$ \\
\hline
\end{tabular}

\section{GENERAL REQUIREMENTS}

3. Mineral wool.-Mineral wool used in the manufacture of industrial insulation for heated equipment shall be composed of rock, slag or glass fibers, made by a process of melting and blowing by steam or air, containing a minimum of oil and unfiberized material.

4. Thermal conductivity.-Thermal conductivity $(k)$, is represented by the rate of flow of thermal energy through each unit area of material when subjected to a temperature gradient of one degree per unit thickness. It is expressed in Btu per hour per square foot per degree fahrenheit temperature difference for a thickness of $1 \mathrm{in}$. of industrial mineral wool insulating products and shall not exceed the maximum value specified under product descriptions below, as determined by the procedure given in Tentative Method of Test for Thermal Conductivity of Materials By Means of the Guarded Hot Plate, A. S. T. M. Designation C $177-42 \mathrm{~T}$ or later revision where applicable.

5. Density.-The average density of industrial mineral wool insulating products shall not vary by more than \pm 10 percent from the density at which the thermal conductivity value specified was determined.

\section{DETAIL REQUIREMENTS}

\section{BLANKET INSULATION}

6. Blanket insulation shall be fabricated of mineral wool; rein forced on one or both sides by metal fabrics of various types and secured with wire ties, asbestos, or glass cord. For installations on which the subsequent application of insulating cement is specified, expanded metal lath shall be furnished on one side of the blankets.

6a. Two classes of blankets are specified herein as determined by the maximum temperature limit recommended by the manufacturer:

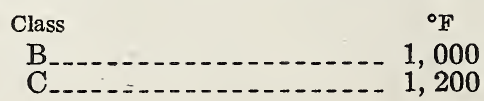

6b. The thermal conductivity of both classes of blankets shall not exceed $0.41 \mathrm{Btu}$ at $200^{\circ} \mathrm{F}$ mean temperature, $0.47 \mathrm{Btu}$ at $300^{\circ} \mathrm{F}$ mean temperature, and $0.53 \mathrm{Btu}$ at $400^{\circ} \mathrm{F}$ mean temperature. 
6c. The density shall be measured in accordance with Tentative Methods of Test for Thickness and Density of Blanket Type Thermal Insulating Materials, A. S. T. M. Designation C 167-41T or later revision.

6d. Standard sizes shall be 24 by 48 in. and 24 by 96 in. Standard thicknesses shall be from 1 to 6 in., inclusive, in not less than 1/2-in. increments. Manufacturing tolerances in all dimensions shall be plus.

\section{BLOCK INSULATION}

7. Block insulation shall be composed of mineral wool fibers bonded together with other ingredients in a permanently effectual manner to form a semirigid or rigid slab.

7a. Three classes of blocks are specified herein as determined by the maximum temperature limit recommended by the manufacturer:

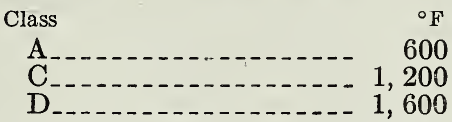

7b. Blocks shall be manufactured with corners square and the sides and ends parallel.

7c. Thermal conductivity of all rlasses of mineral wool blocks shall not exceed $0.50 \mathrm{Btu}$ at $200^{\circ} \mathrm{F}$ mean temperature, $0.53 \mathrm{Btu}$ at $300^{\circ} \mathrm{F}$ mean temperature, and $0.56 \mathrm{Btu}$ at $400^{\circ} \mathrm{F}$ mean temperature.

$7 \mathrm{~d}$. Standard sizes shall be 6 in. and $12 \mathrm{in}$. in width and $18 \mathrm{in}$. and 36 in. in length. Standard thicknesses shall be from 1 to 4 in., inclusive, in not less than $1 / 2$-in. increments. A tolerance of $\pm 1 / 8$ in. shall be allowed in all dimensions.

\section{INSULATING CEMENT}

8. Insulating cement shall be manufactured predominantly of mineral-wool fibers, dry-mixed uniformly with other ingredients.

8a. Two classes of insulating cement are specified as determined by the maximum temperature limit recommended by the manufacturer:

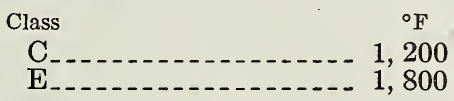

8b. Dry covering capacity and volumetric shrinkage shall be determined according to method described in Tentative Methods of Test for Covering Capacity and Volume Change Upon Drying of Thermal Insulating Cement, A. S. T. M. Designation C 166-41T, or later revision. Volumetric shrinkage of insulating cement shall not exceed 20 percent of the wet coverage, resulting in a minimum dry coverage when properly applied of not less than $45 \mathrm{sq} \mathrm{ft}, 1$ in. thick per $100 \mathrm{lb}$ of dry material.

8c. Adhesion to steel shall meet the requirements of Emergency Specifications for Mineral Wool Thermal Insulating Cement, A. S. T. M. Designation ES-10, or later revision.

$8 \mathrm{~d}$. The thermal conductivity of both classes of insulating cement shall not exceed $0.70 \mathrm{Btu}$ at $200^{\circ} \mathrm{F}$ mean temperature, $0.75 \mathrm{Btu}$ at $300^{\circ} \mathrm{F}$ mean temperature, and $0.80 \mathrm{Btu}$ at $400^{\circ} \mathrm{F}$ mean temperature.

8e. Insulating cement shall be packaged in multiwall, nonreturnable paper bags containing not less than $50 \mathrm{lb}$ net weight. 


\section{PIPE INSULATION}

BLANKET TYPE

9a. Blanket-type insulation shall be fabricated of mineral wool, reinforced on one or both sides by metal fabrics of various types suitably secured by wire ties, asbestos, or glass cord. It shall be furnished in a single layer.

(1) Two classes of blanket-type pipe insulation are specified herein as determined by the maximum temperature limit recommended by the manufacturer:

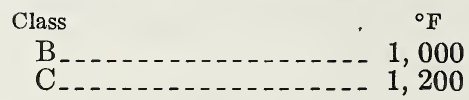

(2) The thermal conductivity of both classes of blanket-type pipe insulation shall not exceed $0.41 \mathrm{Btu}$ at $200^{\circ} \mathrm{F}$ mean temperature, $0.47 \mathrm{Btu}$ at $300^{\circ} \mathrm{F}$ mean temperature, and $0.53 \mathrm{Btu}$ at $400^{\circ} \mathrm{F}$ mean temperature.

(3) The density shall be measured in accordance with Tentative Methods of Test for Thickness and Density of Blanket Type Thermal Insulating Materials, A. S. T. M. Designation C $167-41 \mathrm{~T}$ or later revision.

(4) The standard length of blanket-type pipe insulation shall be $2 \mathrm{ft}$ and shall be fabricated for circumferential wrapping around specified pipe sizes. Standard thicknesses shall be from 1 to 4 in., inclusive, in not less than $1 / 2$-in. increments. Manufacturing tolerances in.all dimensions shall be plus.

\section{MOLDED TYPE}

9b. Molded-type pipe insulation shall be composed of mineral wool fibers bonded together with other ingredients in a permanently effectual manner to form a rigid material.

(1) Two classes of molded-type pipe insulation are specified herein as determined by the maximum temperature limit recommended by the manufacturer:

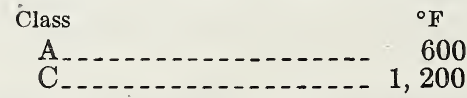

(2) The thermal conductivity of both classes shall not exceed $0.42 \mathrm{Btu}$ at $200^{\circ} \mathrm{F}$ mean temperature, $0.46 \mathrm{Btu}$ at $300^{\circ} \mathrm{F}$ mean temperature, and $0.50 \mathrm{Btu}$ at $400^{\circ} \mathrm{F}$ mean temperature.

(3) It shall be furnished in single- or double-layer thicknesses, in sections or segments to fit standard pipe sizes.

(4) Molded-type pipe insulation shall be manufactured in thicknesses as shown in table 2. The standard length shall be 36 in.; a tolerance of $\pm 1 / 16$ in. in all dimensions shall be allowed. 
TABLE 2.-Molded-type pipe insulation

Thicknesses a for standard-weight steel-pipe sizes

\begin{tabular}{|c|c|c|c|}
\hline \multicolumn{2}{|c|}{ Pipe size } & \multirow{2}{*}{$\begin{array}{l}\text { Standard } \\
\text { thickness }\end{array}$} & \multirow{2}{*}{$\begin{array}{l}\text { Double } \\
\text { standard } \\
\text { thickness }\end{array}$} \\
\hline Nominal & Actual O. D. & & \\
\hline $\begin{array}{l}\text { in. } \\
1 / 2 \\
3 / 4 \\
1 \\
11 / 4 \\
11 / 2\end{array}$ & $\begin{array}{l}\text { in. } \\
0.840 \\
1.050 \\
1.315 \\
1.660 \\
1.900\end{array}$ & $\begin{array}{l}i n . \\
7 / 8 \\
7 / 8 \\
7 / 8 \\
7 / 8 \\
7 / 8\end{array}$ & $\begin{array}{c}\text { in } \\
13 / 4 \\
13 / 4 \\
13 / 4 \\
13 / 4 \\
13 / 4\end{array}$ \\
\hline $\begin{array}{l}2 \\
21 / 2 \\
3 \\
31 / 2 \\
4\end{array}$ & $\begin{array}{l}2.375 \\
2.875 \\
3.500 \\
4.000 \\
4.500\end{array}$ & $\begin{array}{l}11 / 32 \\
11 / 32 \\
11 / 32 \\
11 / 32 \\
11 / 8\end{array}$ & $\begin{array}{l}21 / 16 \\
21 / 16 \\
2116 \\
21 / 16 \\
21 / 4\end{array}$ \\
\hline $\begin{array}{l}41 / 2 b \\
5 \\
6 \\
7 \text { b } \\
8\end{array}$ & $\begin{array}{l}5.000 \\
5.563 \\
6.625 \\
7.625 \\
8.625\end{array}$ & $\begin{array}{l}11 / 8 \\
11 / 8 \\
11 / 8 \\
11 / 4 \\
11 / 4\end{array}$ & $\begin{array}{l}21 / 4 \\
21 / 4 \\
21 / 4 \\
21 / 2 \\
21 / 2\end{array}$ \\
\hline $\begin{array}{c}9 \mathrm{gb} \\
10^{\mathrm{b}} \\
11^{\mathrm{b}} \\
12^{-} \mathrm{ap}\end{array}$ & $\begin{array}{r}9.625 \\
10.750 \\
11.750 \\
12.750 \\
\end{array}$ & $\begin{array}{l}11 / 4 \\
114 \\
11 / 4 \\
11 / 2 \\
11 / 2\end{array}$ & $\begin{array}{l}21 / 2 \\
21 / 2 \\
21 / 2 \\
3 \\
3\end{array}$ \\
\hline
\end{tabular}

a In addition to the thicknesses specified above, molded-type pipe insulation may be manufactured in thicknesses of $1,11 / 2,2,21 / 2,3$, and 4 in. for all nominal pipe sizes.

b These pipe sizes are no longer listed as standard for steel pipe, Simplified Practice Recommendation R57-32.

\section{RECOMMENDED INSTALLATION REQUIREMENTS}

10. The following represents recommended installation requirements, based upon long experience, for maximum service in the use of mineral wool products for insulating heated industrial equipment.

\section{AUXILIARY MATERIAL 1}

11. Finishing cements may be used to provide a smooth, hard surface over insulating materials in locations not subject to excessive moisture or abrasion.

12. Asphaltic weatherproof finish may be used to provide a watertight protective finish over insulating materials in locations where excessive moisture or abrasion are encountered or wherever else specified within its temperature limit. This asphaltic finish shall consist of a fibrated asphalt emulsion, which, for weatherproofing purposes, shall be applied to a minimum dry thickness of $1 / 8$ in. (See paragraph 21c (1) and similar reference to weatherproof finish over the various product forms of mineral wool.)

13. Miscellaneous accessory materials, such as adhesives, attachment devices, canvas, paper, metal fabrics, asbestos-cement sheets, roofing felt, paint, sheet metal, etc., shall be of a type and quality satisfactory for use in the applications hereinafter described.

\section{APPLICATION (GENERAL)}

14. The selection of the economical thickness of mineral wool insulation to be installed is governed largely by the operating temperature maintained, the cost of heat delivered, the number of hours operated per year, and by the effectiveness and applied cost of the insulation.

1 During the war emergency period, some of the auxiliary material described in this standard may be considered critical. When such auxiliary materials are not available owing to Government order, an acceptable alternate material shall be used. 
Other factors which determine insulation thicknesses are the maintenance of precise temperature control; protection against damage by corrosion, freezing, or fire; and personal safety of workmen.

15. The insulation thicknesses to be applied for various operating conditions shall not be less than those recommended in table 3 , unless otherwise approved by the purchaser.

15a. External surfaces of heated multilayer brick constructions shall be insulated to a thickness no greater than that which will result in a safe temperature gradient for all materials used in the composite construction.

16. Expansion joints for insulation shall be provided on equipment operated at temperatures above $600^{\circ} \mathrm{F}$, as specified by the insulation manufacturer or by the applying contractor.

\section{TABLE 3.-Recommended minimum insulation thicknesses}

The insulation thicknesses listed in this table are recommended for indoor locations; for outdoor location increase insulation thickness not less than $1 / 2$ in. For under ground application, thickness may be decreased $1 / 2$ in. when specifled. (See paragraph 14 and 15. )

BLANKET INSULATION

\begin{tabular}{|c|c|c|c|}
\hline Temperature & Thickness & Temperature & Thickness \\
\hline $\begin{array}{l}{ }^{\circ} F \\
\text { Up to } 300 \\
300 \text { to } 500\end{array}$ & in. $\begin{array}{l}1 \\
11 / 2 \\
2\end{array}$ & $\begin{array}{l}{ }^{\circ} \mathrm{F} \\
700 \text { to } 900 \\
900 \text { to } 1,100 \\
1,100 \text { to } 1,200, \ldots\end{array}$ & in. $\begin{array}{l} \\
21 / 2 \\
3 \\
31 / 2\end{array}$ \\
\hline \multicolumn{2}{|l|}{ BLOCK INSULATION } & \multicolumn{2}{|l|}{ INSULATING CEMENT 1} \\
\hline Temperature & Thickness & Temperature & Thickness \\
\hline $\begin{array}{l}\text { Up to } 200 \\
200 \text { to } 400 \\
400 \text { to } 500 \\
500 \text { to } 600 \\
600 \text { to } 700 \\
700 \text { to } 900 \\
900 \text { to } 1,100 \\
1,100 \text { to } 1,300 \\
1,300\end{array}$ & in. $\begin{array}{l} \\
1 \\
11 / 2 \\
2 \\
21 / 2 \\
3 \\
31 / 2 \\
4 \\
41 / 2 \\
5\end{array}$ & $\begin{array}{l}\text { Up to } 200 \\
200 \text { to } 400 \\
400 \text { to } 500 \\
500 \text { to } 600 \\
600 \text { to } 700 \\
700 \text { to } 900 \\
900 \text { to } 1,100 \\
1,100 \text { to } 1,300 \\
1,300 \text { to } 1,600 \\
1,600\end{array}$ & in. $\begin{array}{l}1 \\
11 / 2 \\
21 / 2 \\
3 \\
31 / 2 \\
41 \\
41 / 2 \\
5 \\
51 / 2 \\
61 / 2\end{array}$ \\
\hline
\end{tabular}

PIPE INSULATION

\begin{tabular}{|c|c|c|c|c|c|c|c|}
\hline \multicolumn{4}{|c|}{ Blanket-type } & \multicolumn{4}{|c|}{ Molded-type } \\
\hline \multirow[b]{2}{*}{ Temperature } & \multicolumn{3}{|c|}{ Thickness } & \multirow[b]{2}{*}{ Temperature } & \multicolumn{3}{|c|}{ Thickness } \\
\hline & $\begin{array}{l}\text { Pipes } \\
2 \text { in. to } \\
4 \text { in. }\end{array}$ & $\begin{array}{l}\text { Pipes } \\
4 \text { in. to } \\
6 \text { in. }\end{array}$ & $\begin{array}{c}\text { Pipes } \\
6 \text { in. } \\
\text { and up }\end{array}$ & & $\begin{array}{l}\text { Pipes } \\
\text { below } \\
2 \text { in. }\end{array}$ & $\begin{array}{l}\text { Pipes } \\
2 \text { in. to } \\
4 \text { in. }\end{array}$ & $\underset{\substack{\text { Pipes } \\
\text { up }}}{ }$ \\
\hline $\begin{array}{l}{ }^{\circ} \mathrm{F} \\
150 \text { to } 2500 \\
250 \text { to } 350 \\
350 \text { to } 450 \\
450 \text { to } 550 \\
550 \text { to } 650 \\
650 \text { to } 750 \\
750 \text { to } 900 \\
900 \text { to } 1,050 \\
1,050 \text { to } 1,200\end{array}$ & $\begin{array}{c}\text { in. } \\
1 \\
1 \\
1 \\
1 \\
11 / 2 \\
11 / 2 \\
2 \\
2 \\
21 / 2\end{array}$ & $\begin{array}{c}\text { in. } \\
1 \\
1 \\
1 \\
11 / 2 \\
11 / 2 \\
2 \\
2 \\
21 / 2 \\
31 / 2\end{array}$ & $\begin{array}{c}\text { in. } \\
1 \\
1 \\
11 / 2 \\
11 / 2 \\
2 \\
2 \\
21 / 2 \\
3 \\
4\end{array}$ & $\begin{array}{l}{ }^{\circ} \mathrm{F} \\
\mathrm{Up} \text { to } 275 \\
275 \text { to } 350 \\
350 \text { to } 425 \\
425 \text { to } 500 \\
500 \text { to } 600 \\
600 \text { to } 750 \\
750 \text { to } 900 \\
900 \text { to } 1,050 \\
1,050 \text { to } 1,200\end{array}$ & 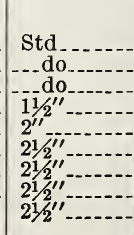 & 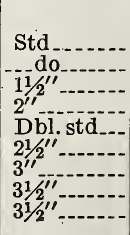 & 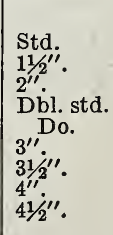 \\
\hline
\end{tabular}

1 Usually applied over blankets and blocks $1 / 2$ in. thick as a base coat for desired finish. For built-up applications on irregular surfaces, thicknesses may be used up to the practical limit. 
17. Adequate protection shall be provided to prevent the entrance of moisture into the insulating material. Particular care shall be taken around openings and connections.

18. All mineral wool insulating products and accessory materials shall be installed in a neat, workmanlike manner in accordance with the following recommendations and subject to the approval of the purchaser.

\section{BLANKET INSULATION}

19. Preparation of surface.

19a. The surface to be insulated shall be carefully inspected and all loose rust, scale, or dirt removed and leaks or damage repaired.

$19 \mathrm{~b}$. Suitable anchorage for the blankets shall be provided in the form of wire cables, nuts, clip angles, or No. 9-gage galvanized wires, welded or otherwise, securely affixed to the surface on specified centers.

20. Installation of blankets.

20a. On curred surfaces, blankets of specified thickness (see table 3) shall be secured to the supports with the expanded lath side exposed, edges tightly butted together, then banded or wired circumferentially, and laced together along the edges with No. 16-gage galvanized wire. (See figs. 1, 2, and 4.)

$20 \mathrm{~b}$. On flat surfaces, blankets shall be applied with the expanded lath exposed by impaling them over No. 9-gage galvanized wires welded perpendicular to the surface. The extending ends of the wires shall then be bent upward at right angles and pushed into the blanket. The blankets shall be tightly butted, then laced together at all edges with No. 16-gage galvanized wire and further reinforced as required. (See fig. 3.)

\section{Application of finish.}

21a. After the blankets are in position and carefully secured, a $1 / 4$-in. layer of mineral wool insulating cement shall be applied. This coat shall be forced well into the expanded metal lath to form a strong key. Sufficient cement shall be applied to level off the surface. A second $1 / 4-$ in. troweled coat of insulating or finishing cement shall be applied after the first coat has dried. Portland cement may be added to this coat to provide a harder finish.

$21 \mathrm{~b}$. Insulation located indoors and not exposed to moisture or abrasion may be further finished as described below.

(1) When specified, a 6- or 8-oz. canvas jacket shall be sewed or pasted smoothly in place. If sewed, stitches shall be spaced not more than $1 / 3$ in. apart, with seams located where least visible.

(2) When specified, a layer of asphaltic weatherproof finish may be applied instead of canvas. After the second coat of cement has thoroughly dried, 1-in. galvanized wire netting shall be stretched tightly over the surface and wired in place with No. 16-gage galvanized wire. Asphaltic finish shall then be applied sufficiently thick (approximately $1 / 4$ in. thick, wet) to provide a minimum dry thickness of $1 / 8$ in., troweling it well into the wire netting. 


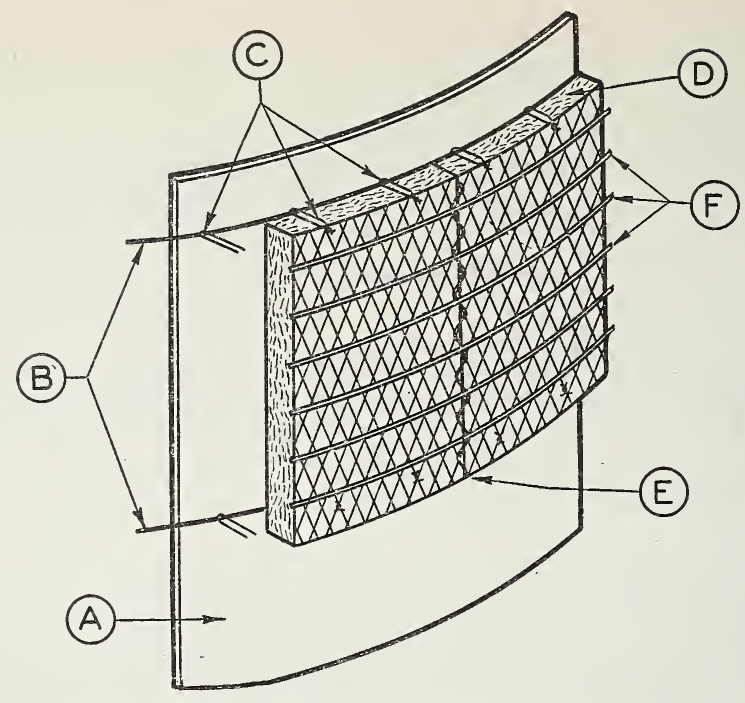

FIGURE 1.-Method of securing mineral wool blankets on curved surfaces.

$A$, Bare surface; $B$, No. 9-gage galvanized-wire girdles pulled tight around curved surfaces, spaced $4 \mathrm{ft}$ on centers; $C$, blankets affixed to No. 9-gage girdles with No. 16-gage galvanized hairpin wires, 12 in. on centers; $D$, blanket insulation with expanded lath side exposed; $E$, blanket edges laced with No. 16-gage galvanized wires; $F$, blankets secured with $1 / 2^{-}$or $3 / 4^{-i n}$. galvanized bands spaced approximately 8 in. on centers.

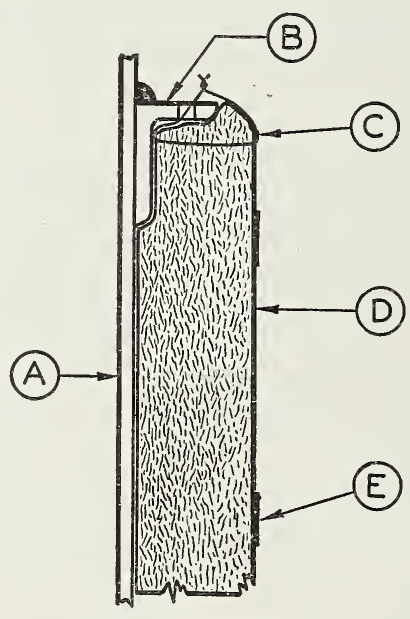

Figure 2.-Alternate method of affixing mineral wool blankets.

$A$, Bare surface; $B$, punched clip angles welded to surface, spaced $8 \mathrm{ft}$ on horizontal centers; $C$, blankets hung temporarily from angles with No. 12-gage galvanized wires; $D$, blanket insulation 1 in. thicker than outstanding leg of angle; $E$, blanket secured with $1 / 2-$ or $3 / 4-i n$. galvanized bands spaccd approximately 8 in. on centers. 


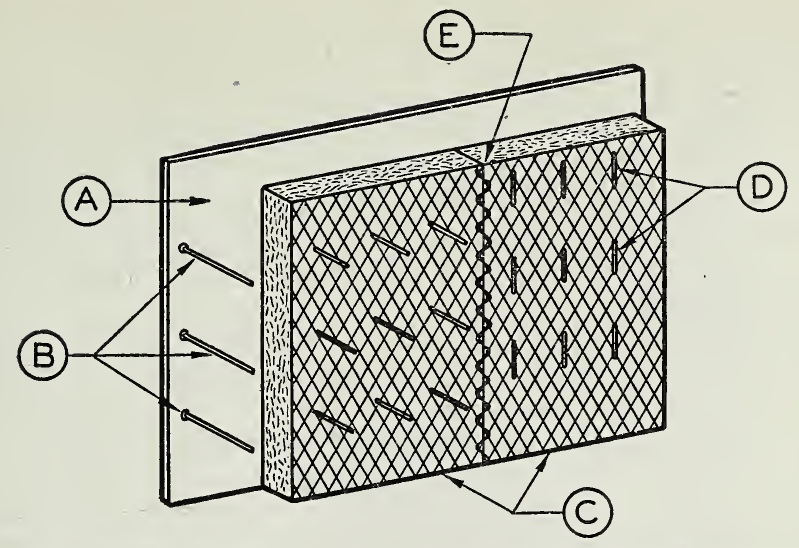

FIGURE 3.-Alternate method of affixing mineral wool blankets on flat surfaces.

$A$, Bare surface; $B$, No. 9-gage galvanized wires of specified length welded perpendicular to surface, spaced approximately 8 in. on centers; $C$, blankets impaled on No. 9-gage galvanized wires with expanded-lath side exposed; $D$, No. 9-gage galvanized wires bent up and pressed into the blankets; $E$, blanket edges laced with No. 16-gage galvanized wires.

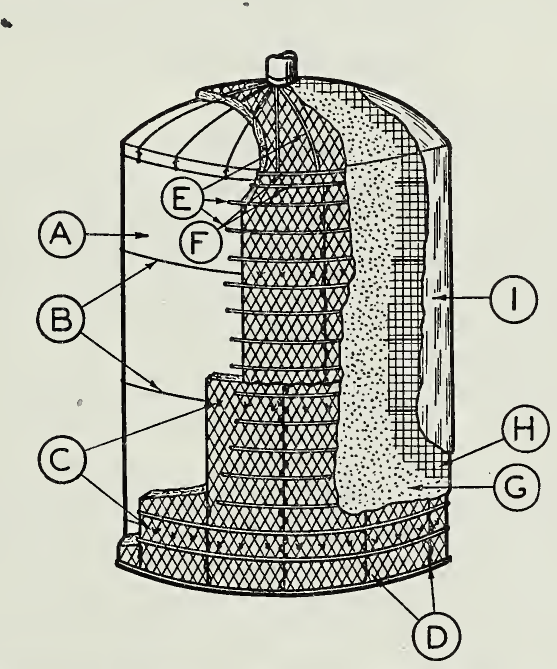

FIGURE 4.-Application of mineral wool blanket insulation on curved surfaces.

$A$, Bare surface; $B$, No. 9-gage galvanized-wire girdles spaced $4 \mathrm{ft}$ on centers; $C$, blanket insulation $2 \mathrm{ft}$ by 8 ft, wired to girdles; $D$, blanket edges laced with No. 16-gage galvanized wires; $E$, $1 / 2-$ or $3 / 4$-in. galvanized bands spaced approximately 8 in. on centers; $F$, two or more bands at top; $G$, insulating cement; $H, 1$-in. galvanized wire netting secured in place with No. 16-gage galvanized wires; $I$, finishing cement or asphaltic finish. 
21c. Insulation located outdoors or exposed to moisture or abrasion shall be protected by one of the methods described below.

(1) After the cement has thoroughly dried, 1-in. galvanized wire netting shall be stretched tightly over the surface and wired in place with No. 16-gage galvanized wire. Asphaltic finish shall then be applied sufficiently thick (approximately $1 / 4$ in. thick, wet) to provide a minimum dry thickness of $1 / 8$ in., troweling it well into the wire netting.

(2) When specified on smooth regular surfaces, the cement and asphaltic coatings may be omitted, and the surface weatherproofed instead with a sheet-metal jacket. The sheet-metal jacket shall be no lighter than No. 28 gage, single or double galvanized, suitably anchored to the surface. Seams shall be lapped 2 in. against the weather and secured with metal screws, or provided with a locked or flange-crimped joint or otherwise sealed, to prevent the entry of moisture. After providing for expansion and contraction of the metal jacket, it shall be secured in place with $1 / 2$-in. or $3 / 4$-in. galvanized metal bands, machine-stretched and crimped, on specified centers.

\section{BLOCK INSULATION}

22. Preparation of surface.

22a. The surface to be insulated shall be carefully inspected and all loose rust, scale, or dirt shall be removed and leaks or damage repaired. Brick surfaces shall be made true and even.

$22 \mathrm{~b}$. Suitable anchorage or support for the blocks shall be provided where required, by securely affixing wire cables, nuts, clip angles, or rods to the surface on specified centers.

23. Installation of blocks.

23a. On curved surfaces, blocks of specified thickness (see table 3) shall be applied using staggered joint construction. After securing the blocks in place with bands applied circumferentially, 1-in. galvanized wire netting shall be tightly stretched, secured over the surface and laced with No. 16-gage galvanized wires. (See fig. 5.)

$23 \mathrm{~b}$. On flat surfaces, blocks of specified thickness (see table 3 ) shall be applied using staggered-joint construction. When reinforcing is required, the blocks shall be secured in place with bands or wires spaced on specified centers. When specified, corners shall be protected with corner bead.

(1) Where a subsequent application of insulating cement is specified, 1-in. galvanized wire netting shall be tightly stretched and secured over the surface of the blocks. (See fig. 6.)

23c. When blocks are installed between brick or other structural supports, the anchors, insulating cement, and other finish shall be omitted. (See fig. 7.) 
24. Application of finish.

24a. After the blocks are secured in place and reinforced with 1-in. galvanized wire netting, a $1 / 4$-in. coat of insulating cement shall be applied. This coat shall be forced well into the cracks between adjacent blocks, applying sufficient material to level off the surface. A second $1 / 4$-in. troweled coat of insulating or finishing cement shall be applied after the first coat has dried. Portland cement may be added to this coat to provide a harder finish.

$24 \mathrm{~b}$. Insulation located indoors and not exposed to moisture or abrasion may be further finished as described below. (See figs. 5 and 6.)

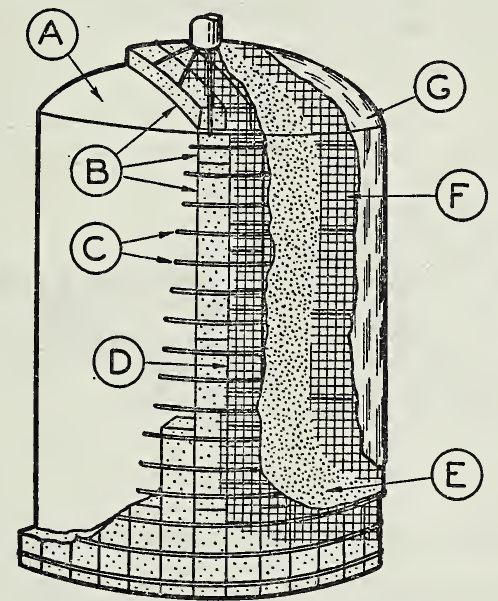

FiguRe 5.-Application of mineral wool block insulation on curved surfaces.

$A$, Bare surface; $B$, mineral wool blocks applied with joints staggered; $C$, 1/2- or $3 / 4$-in. galvanized bands spaced approximately 8 in. on centers; $D$, 1-in. galvanized wire netting secured in place with No. 16gage galvanized wires; $E$, insulating cement; $F$, i-in galvanized-wire netting secured in place with No.16gage galvanized wires; $G$, finishing cement or asphaltic finish.

(1) When specified, a $6-$ or $8-o z$ canvas jacket shall be sewed or pasted smoothly in place. If sewed, stitches shall be spaced not more than $1 / 3$ in. apart, with seams located where least visible.

(2) When specified, a layer of asphaltic weather-proof finish may be applied instead of canvas. After the second coat of cement has thoroughly dried, 1-in. galvanizedwire netting shall be stretched tightly over the surface and wired in place with No. 16-gage galvanized wire. Asphaltic finish shall then be applied sufficiently thick (approximately $1 / 4$ in. thick, wet.) to provide a minimum dry thickness of $1 / 8$ in., troweling it well into the wire netting.

24c. Insulation located outdoors or exposed to moisture or abrasion shall be protected by one of the methods described below.

(1) After the cement has thoroughly dried, 1-in. galvanizedwire netting shall be stretched tightly over the surface 

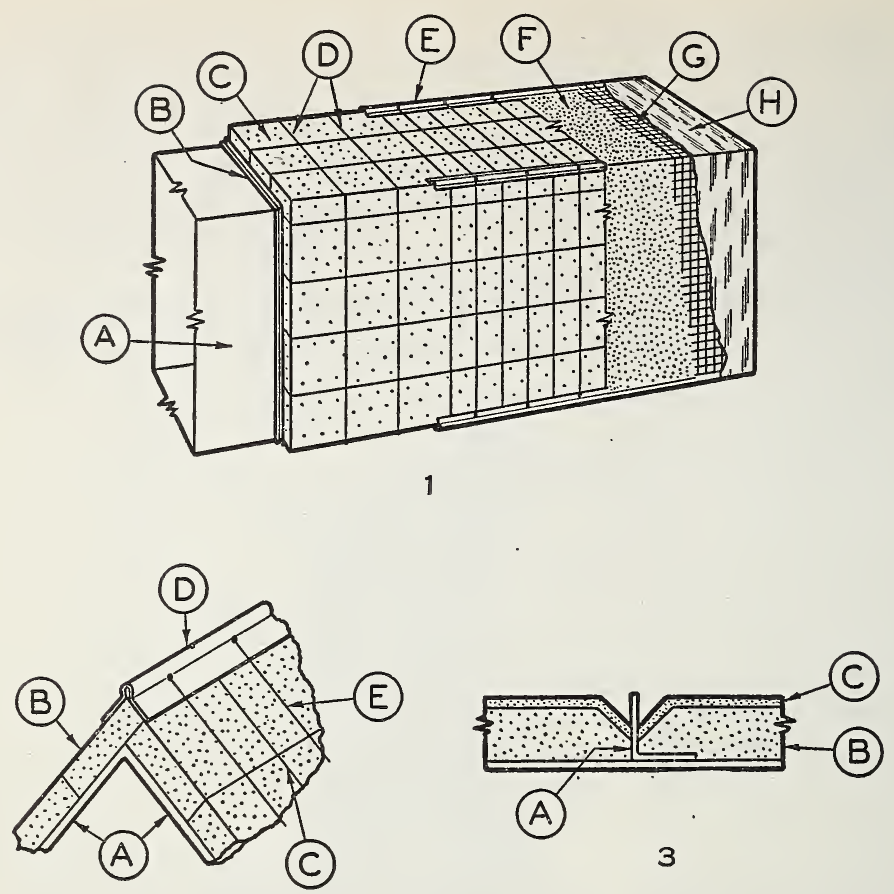

2

FigURE 6.-Application of mineral wool blocks on flat or rectangular surfaces.

Sketch 1: Application where insulation thickness is greater than stiffener height. $A$, bare surface; $B$, stiffener ribs; $C$, mineral wool blocks; $D$, No. 16-gage galvanized reinforcing wires or 16-in. galvanized bands applied over blocks; $E$, corner bead secured over blocks at corners with No. 16-gage galvanized wires; $F$, insulating cement; $G, 1$-in. galvanized wire netting stretched tightly over insulating cement and wired in place; $H$, finishing cement or asphaltic finish.

Sketch 2: Enlarged details showing application of corner bead. $A$, metal duct; $B$, mineral wool blocks; $C$, No. 16-gage galvanized wire over blocks; $D$, corner bead; $E$, No. 16-gage galvanized wires drawn through perforations in corner bead.

Sketch 3 : A pplication where insulation thickness is equal to or less than stiffener height. $A$, stiffener; - $B$, mineral wool blocks; $C$, insulating cement and specified finish beveled back at rib.

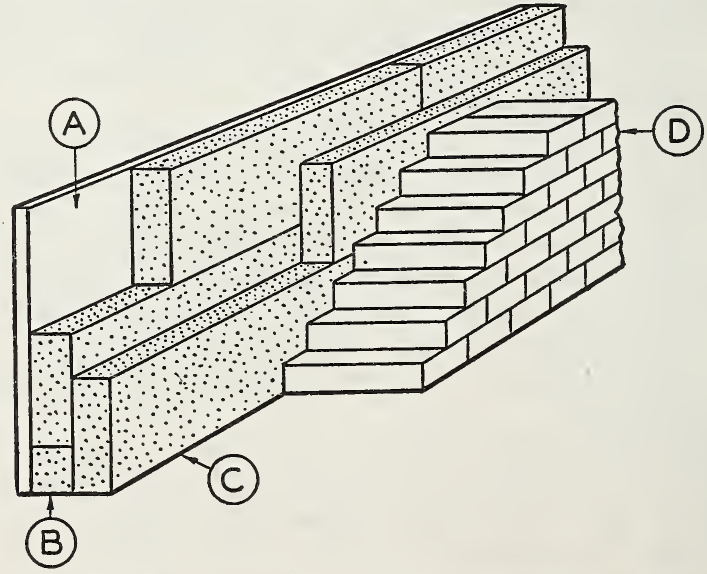

FigURE 7.-Application of mineral wool blocks between structural supports.

$A$, bare surface; $B$, first layer of mineral wool blocks against steel casing; $C$, second layer of blocks applied with all joints staggered; $D$, brick. 
and wired in place with No. 16-gage galvanized wire. Asphaltic finish shall then be applied sufficiently thick (approximately $1 / 4$ in. thick, wet.) to provide a minimum dry thickness of $1 / 8$ in., troweling it well into the wire netting.

(2) When specified, the cement and asphaltic coatings may be omitted, and the surface weather-proofed instead with a sheet-metal jacket. The sheet-metal jacket shall be no lighter than No. 28 gage, single or double galvanized, suitably anchored to the surface. Seams shall be lapped 2 in. against the weather and secured with metal screws, or provided with a locked or fiange-crimped joint to prevent the entry of moisture. After providing for expansion and contraction of the metal jacket, it shall be secured in place with $1 / 2$-in. or $3 / 4$-in. galvanized metal bands, machine-stretched and crimped, on specified centers.

\section{INSULATING CEMENT (BUILT-UP APPLICATIONS)}

\section{Preparation of surface.}

25a. The surface to be insulated shall be carefully inspected and all loose rust, scale, or dirt removed and leaks or damage repaired. Paint or grease shall be removed with a caustic solution which shall then be washed off with water.

25b. Anchorage for the insulating cement shall be provided as required, in the form of clip angles, nuts, rods, or masonry nails of proper size. Additional support is recommended for insulating cement applied on light-gage metallic surfaces, or when surface expansion and contraction is excessive.

$25 \mathrm{c}$. When possible, the surface to be insulated shall be kept hot to facilitate drying.

26. Installation of insulating cement.

26a. Insulating cement shall be mixed with clean fresh water to troweling consistency before application.

$26 \mathrm{~b}$. On curved or flat steel surfaces, insulating cement of specified thickness (see table 3) shall be built up in separate coats not greater than $3 / 4$ in. thick. The first coat shall be spotted on by hand then completely roughed in. Subsequent coats, $3 / 4$ in. thick or less, shall be applied after the preceding coats have dried until the total specified thickness is reached. (See fig. 8.)

(1) A reinforcing layer of 1-in. galvanized-wire netting shall be applied between every second coat of insulating cement, stretched tightly over the dry cement and securely wired in place with No. 16-gage galvanized wire when: (a) the total insulation thickness specified is greater than 1 in., (b) the cement is to be applied to the underside of equipment, (c) the insulated equipment will be subjected to vibration.

26c. On heated brick surfaces, insulating cement shall be applied to a thickness which will result in a safe temperature gradient for all materials used in the composite construction. Where reinforcing is required masonry nails approximately $1 \frac{1}{2}$ in. long shall be driven into the mortar joints on approximately 8 - to 12 -in. centers so that the 
heads extend $3 / 4$ in. from the surface of the bricks. The first layer of insulating cement shall be applied nearly flush with the nail heads; 1-in. galvanized wire netting shall then be stretshed tightly over the dry cement and secured to the nails. The second layer of insulating cement shall be applied approximately $1 / 2$ to $3 / 4$ in. thick. (See fig. 9.)

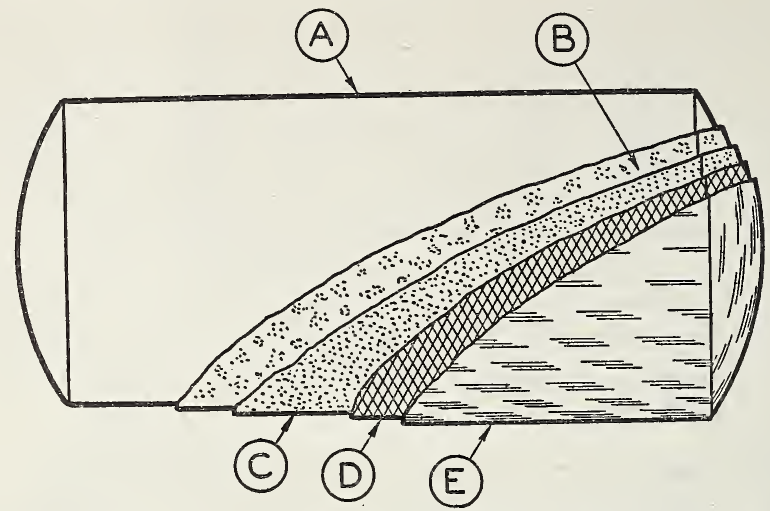

FIGURE 8.-Application of mineral wool insulating cement on curved steel surfaces. $A$, Cleaned bare surface; $B$. first coat of insulating cement spotted on roughly by hand; $C$, second coat of insulating cement; $D, 1$-in. galvanized wire netting; $E$, finishing cement or asphaltic finish.

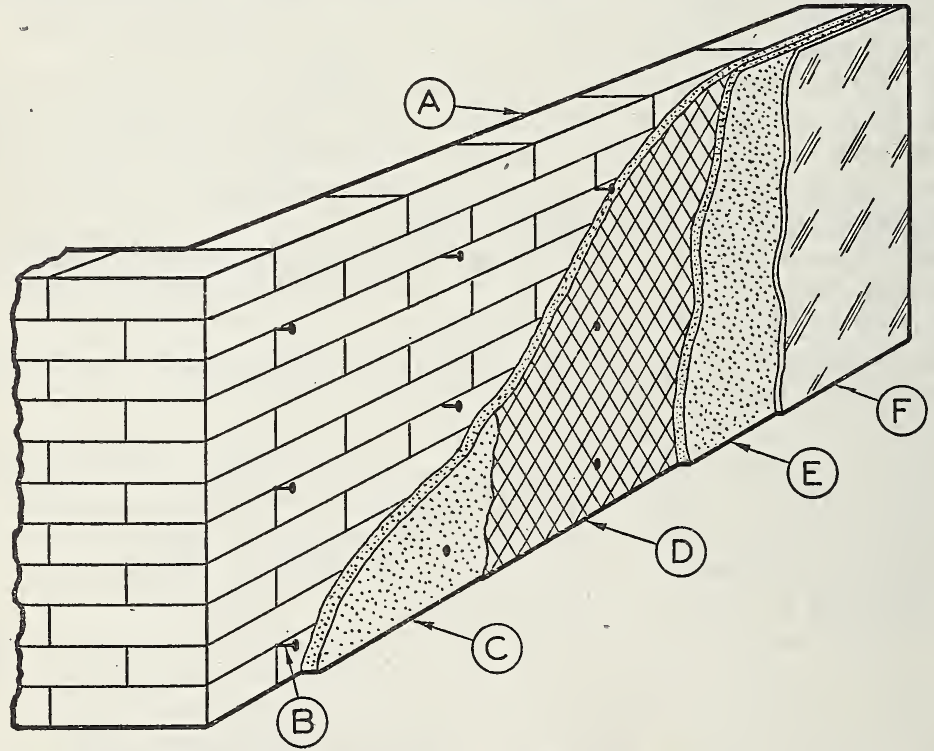

Figure 9.-Application of mineral wool insulating cement on brick surfaces.

$A$, Brick wall; $B$, masonry nails spaced 8 to 12 in. on centers, extending approximately $3 / 4$ in. from hricks; $C$, first coat of insulating cement applied nearly tush with nail heads; $D$, 1-in. galvanized wire netting secured to nail heads; $E$, second coat of insulating cement; $F$, finishing cement or asphaltic finish.

(1) If the insulated surface is to be weatherproofed, No. 16gage galvanized hairpin wires shall be affixed to the nail heads and permitted to extend through the second layer of insulating cement to provide anchorage for the weatherproof finish. 
27. Application of finish.

27a. Insulating cement located indoors and not exposed to moisture or abrasion shall be finished, when specified, with a 1/4-in. troweled coat of finishing cement. Portland cement may be added to provide a harder finish.

(1) When specified, a 6- or 8-oz. canvas jacket shall be sewed or pasted smoothly in place. If sewed, stitches shall be spaced not more than $1 / 3$ in. apart, with seams located where least visible.

(2) When specified, a layer of asphaltic weatherproof finish shall be applied instead of canvas. After the cement has thoroughly dried, 1-in. galvanized wire netting shall be stretched tightly over the surface and wired in place with No. 16-gage galvanized wire. Asphaltic finish shall then be applied sufficiently thick (approximately $1 / 4$ in. thick, wet.) to provide a minimum dry thickness of $1 / 8$ in., troweling it well into the wire netting.

$27 \mathrm{~b}$. Insulating cement located outdoors, or exposed to moisture or abrasion, shall be finished with an asphaltic weatherproof finish.

(1) A $1 / 4$-in. coat of finishing cement shall be applied when specified, to which portland cement may be added to provide a harder finish.

(2) After the cement has thoroughly dried, 1-in. galvanized wire netting shall be stretched tightly over the surface and wired in place with No. 16-gage galvanized wire. Asphaltic finish shall then be applied sufficiently thick (approximately $1 / 4$ in. thick, wet.) to provide a minimum dry thickness of $1 / 8$ in., troweling it well into the wire netting. (See figs. 8 and 9.)

\section{BLANKET-TYPE PIPE INSULATION}

28. Installation on pipes.

28a. Blanket-type pipe insulation of specified thickness (see table 3) shall be applied on pipes and long radius bends of 2-in. diameter or greater.

(1) Before applying, the insulation shall first be formed roughly to fit the pipe. Pipe insulation shall be spaced a sufficient distance from flanges to permit removal of the bolts when flanges are opened. Adjacent lengths shall be butted closely together and laced with No. 16gage galvanized wire. The ends of wire loops shall be bent over and pressed into the insulation to leave no sharp projections. (See fig. 10.)

(2) When specified, blanket-type pipe insulation shall be furnished with an integral galvanized-metal jacket. It shall be applied snugly around the pipe and bolted along the flanged longitudinal joint. No further finish is required.

29. Installation on valves, flanges, and fittings.

29a. Valves, flanges, and fittings 6 in. in diameter or larger shall be insulated with blanket-type pipe insulation of thickness equal to insulation on adjacent piping. The insulation shall be formed to fit by cutting it along the circumferential edges, then secured in place by 
wiring the longitudinal joint. All cut edges shall be laced together with No. 16-gage galvanized wire and the ends of wire loops bent over and pressed into the insulation to leave no sharp projections. (See fig. 11.)

$29 \mathrm{~b}$. As alternate applications on valves, flanges, and fittings, insulating cement or block insulation shall be used.

(1) Insulating cement shall be built-up in $3_{4}$-in. coats to a thickness equal to the insulation on adjacent piping. (See paragraph 26a.)

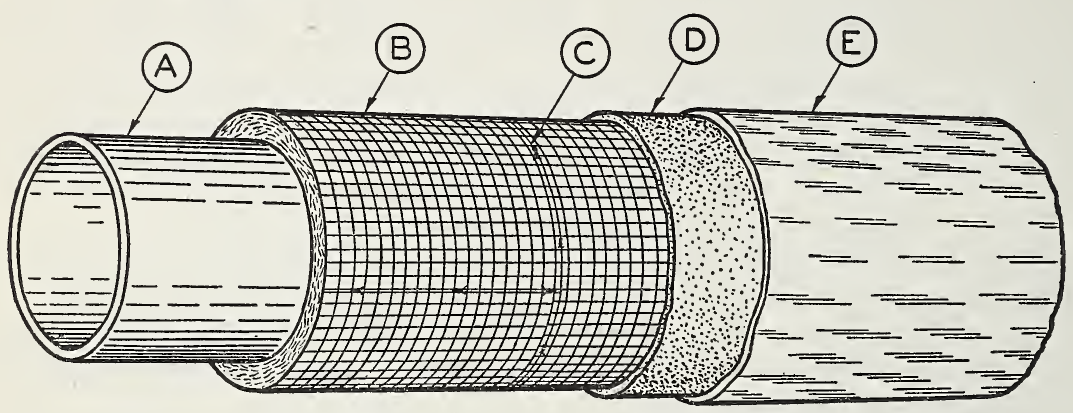

Figure 10.-Application of blanket-type mineral wool pipe insulation on pipes.

$A$, bare pipe; $B$, blanket-type pipe insulation wrapped circumferentially around bare pipe; $C$, joints secured with No. 16-gage galvanized wires; $D$, insulating cement; $E$, asphaltic or other specified finish.

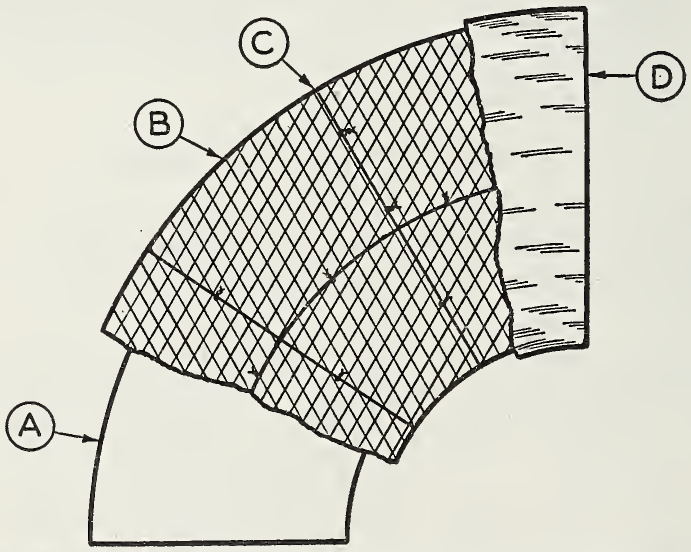

FIGURE 11.-Application of blanket-type mineral wool pipe insulation on large valves and fittings.

$A$, bare fitting; $B$, blanket-type pipe insulation; $C$, joints secured with No. 16-gage galvanized wires; $D$, in sulating cement or other specified finish.

(2) Blocks of a thickness $\frac{1}{2} 2$ in. less than the insulation on adjacent piping shall be carefully fitted and wired securely in place. A $1 / 4$-in. coat of insulating cement shall then be applied, troweling it well into the cracks between adjacent blocks. 
30. Application of finish.

30a. Blanket-type pipe insulation located indoors and not exposed to moisture or abrasion shall be finished as described below. (See fig. 10.)

(1) Pipes, valves, flanges, and fittings shall be finished, when specified, with a canvas jacket sewed or pasted over a layer of flameproofed paper, 1/16-in.-thick asbestos paper, or a $1 / 4$-in. coat of insulating or finishing cement. If sewed, stitches shall be spaced not more than 1/3-in. apart, with seams located where least visible.

(2) Pipes, valves, flanges, and fittings may be finished with asphaltic finish when specified. A 1/4-in. coat of insulating or finishing cement shall be applied and when the cement has thoroughly dried, 1-in. galvanized-wire netting shall be stretched tightly over the surface and wired in place with No. 16-gage galvanized wire. Asphaltic finish shall then be applied sufficiently thick (approximately $1 / 4 \mathrm{in}$. thick, wet) to provide a minimum dry thickness of $1 / 8$ in., troweling it well into the wire netting.

(3) When a roofing-felt finish is specified it shall be smoothsurface asbestos asphalt-saturated, weighing not less than $55 \mathrm{lb}$. per roll of $108 \mathrm{sq}$. ft. Seams shall be lapped at least 2 in. against the weather and when specified, shall be sealed with lap cement. The roofing-felt jacket shall then be secured in place with copper wires or galvanized bands spaced on specified centers.

30b. Blanket-type pipe insulation located outdoors or exposed to moisture or abrasion shall be weatherproofed as described below.

(1) Pipes, valves, flanges, and fittings shall be finished with a sheet-metal jacket, roofing-felt, or asphaltic finish, as specified.

(a) Sheet-metal jackets shall be no lighter than No. 28 gage, single or double galvanized. Seams shall be lapped 2 in. against the weather and secured in place with 1/2- or 3/4-in. galvanized metal bands, machine-stretched and crimped, on specified centers.

(b) When a roofing-felt finish is specified it shall be smoothsurface asbestos asphalt-saturated, weighing not less than $55 \mathrm{lb}$. per roll of $108 \mathrm{sq}$. ft. Seams shall be lapped at least 2 in. against the weather and when specified, shall be sealed with lap cement. The roofing-felt jacket shall then be secured in place with copper wires or galvanized bands spaced on specified centers.

(c) Pipes, valves, flanges, and fittings may be finished with asphaltic finish when specified. A 1/4-in. coat of insulating or finishing cement shall be applied and when the cement has thoroughly dried, 1-in. galvanized wire netting shall be stretched tightly over the surface and wired in place with No. 16-gage galvanized wire. Asphaltic finish shall then be applied sufficiently thick (approximately $1 / 4$ in. thick, wet) to provide a minimum dry thickness of $1 / 8$ in., troweling it well into the wire netting. 


\section{MOLDED-TYPE PIPE INSULATION}

31. Installation on pipes.

31a. Molded-type mineral wool pipe insulation of specified thickness (see table 3) shall be applied in sectional or segmental form, of single- or double-layer construction, as specified. At flanges, pipe covering shall be spaced a sufficient distance from the flanges to permit easy removal of bolts when flanges are opened.

(1) Adjacent pieces of sectional pipe insulation shall be butted closely together and banded in place. (See fig. 12.)

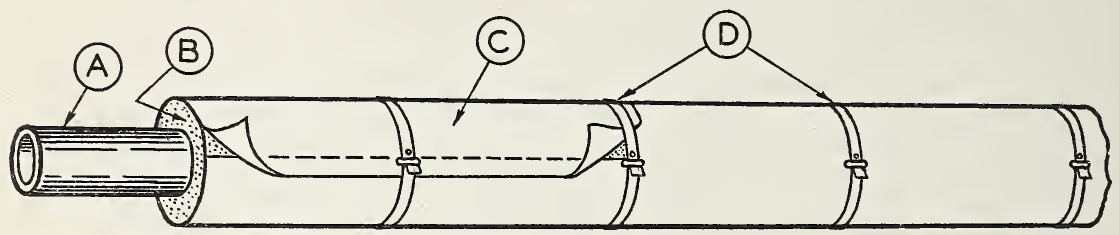

FIGURE 12.-Application of mineral wool sectional pipe insulation single-layer. $A$, Bare pipe; $B$, sectional pipe insulation; $C$, canvas jacket or other specified finish; $D$, metal bands.

(2) Segmental pipe insulation should be secured in place with separate loops of No. 16-gage galvanized wire, spaced on 8- to 12 -in. centers, depending on the pipe size and insulation thickness. Ends of wire loops shall be bent over and pressed into the insulation, leaving no sharp projections. Insulating cement shall then be troweled well into any cracks between adjacent segments. (See fig. 13.)

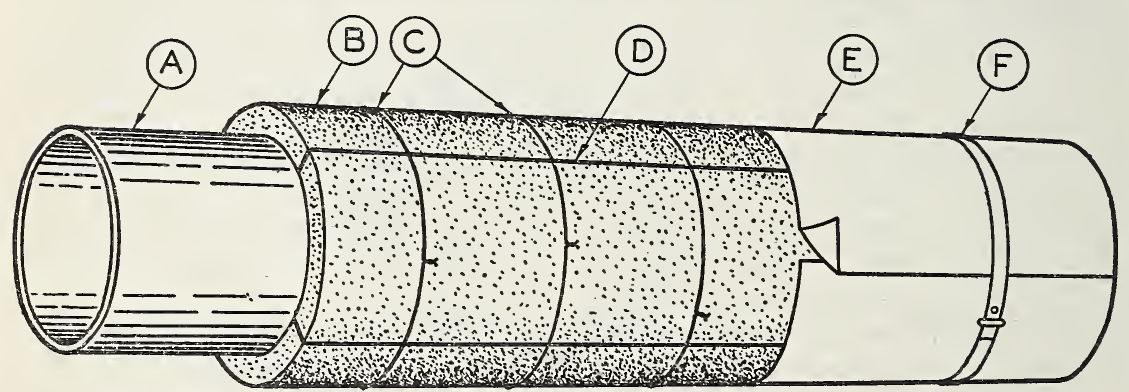

Figure 13.-Application of mineral wool segmental pipe insulation.

$A$, Bare pipe; $B$, segmental pipe insulation; $C$, No. 16-gage galvanized wires; $D$, insulating cement when required; $E$, canvas jacket or other specified finish; $F$, metal bands.

(3) Double-layer pipe insulation, either in sectional or segmental form, shall be applied with circumferential and longitudinal joints staggered, omitting the canvas jacket between layers. The first layer shall be wired in place with separate loops of No. 16-gage galvanized wire spaced on 8- to 12-in. centers. The second layer shall be applied snugly over the first layer and secured in place. (See fig. 14.)

32. Installation on valves, flanges, and fittings.

32a. Valves, flanges, and fittings shall be covered with insulating cement, block insulation, or molded-type pipe insulation, as specified. 


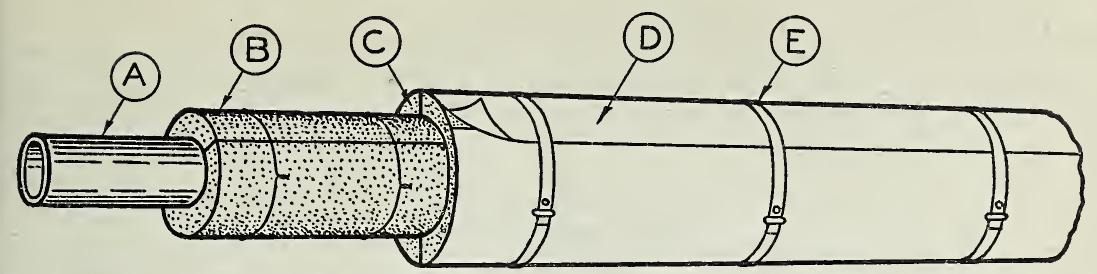

FIGURE 14.-Application of mineral wool sectional pipe insulation, double-layer. $A$, Bare pipe; $B$, first layer secured with No. 16-gage galvanized wires; $C$, second layer applied with all joints staggered; $D$, canvas jacket or other specified finish; $E$, metal bands.

(1) Insulating cement shall be built up in separate coats no greater than $3 / 4$ in. thick, to a thickness equal to the insulation on adjacent piping. (See paragraph 26a and fig. 15.)

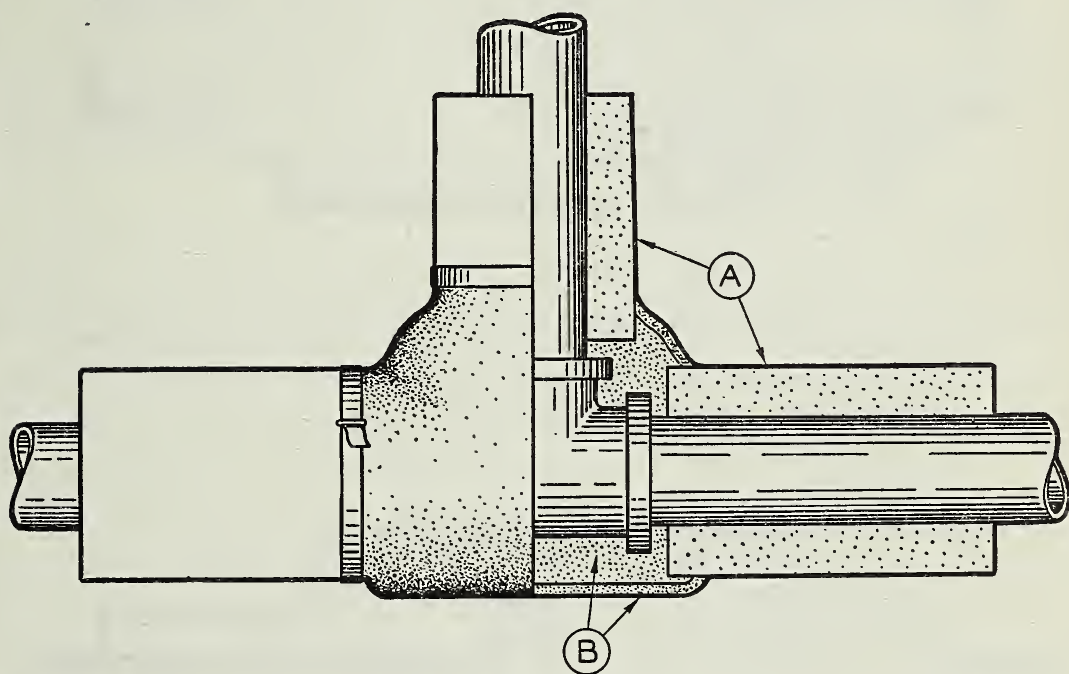

Figure 15.-Application of mineral wool insulating cement to valves, flanges, and fittings.

$A$, Sectional pipe insulation; $B$, insulating cement and other specified finish.

(2) Blocks of a thickness $1 / 2$ in. less than the insulation on adjacent piping shall be carefully installed on large fittings (approximately $4 \mathrm{in}$. and up in diameter) and secured in place with No. 16-gage galvanized wire. A $1 / 4$-in. coat of insulating cement shall then be applied, troweling it well into the cracks between adjacent blocks. (See fig. 16.)

(3) Molded-type pipe insulation may be used to insulate flanged couplings. Rings of sectional pipe covering $1 \frac{1}{2}$ to 2 in. wide should be wired in place on each side of the flange, selecting an insulation thickness that will provide an outside diameter equal to or greater than the flange diameter. A piece of sectional pipe insulation long enough to cover the flange should then be banded in place. (See fig. 17.) 
33. Application of finish located indoors.

33a. Molded-type pipe insulation located indoors and not exposed to moisture or abrasion shall be finished with a canvas jacket.

(1) The factory-weight canvas jacket furnished shall be drawn

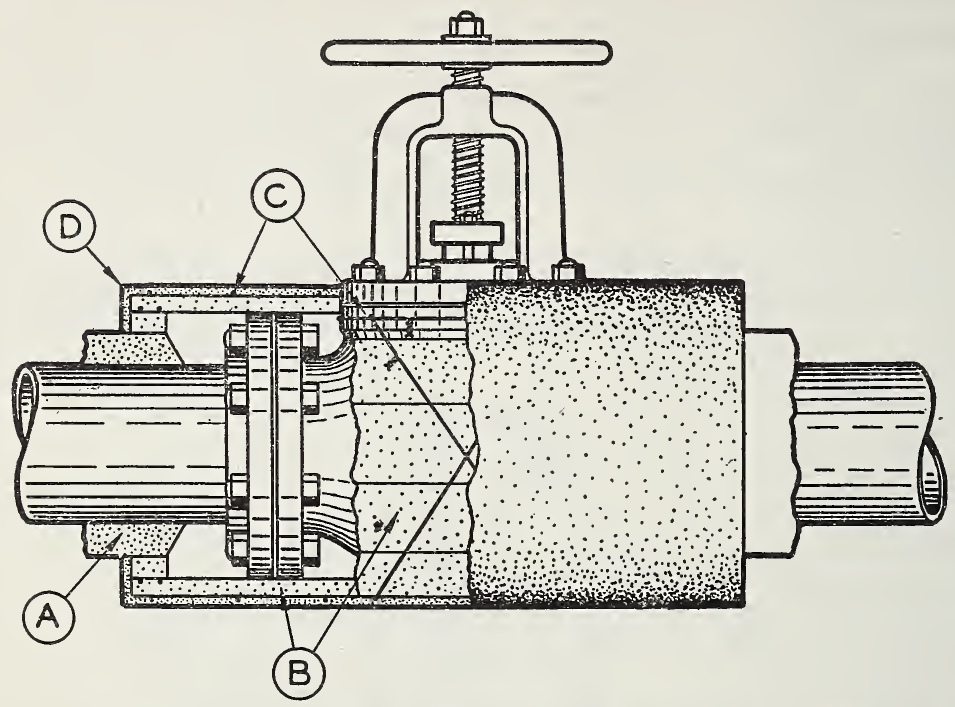

FIgure 16.-Application of mineral wool block insulation to large fittings.

$A$. Pipe insulation; $B$, block insulation; $C$, No. 16-gage galvanized wires; $D$, insulating cement or other specified finish.

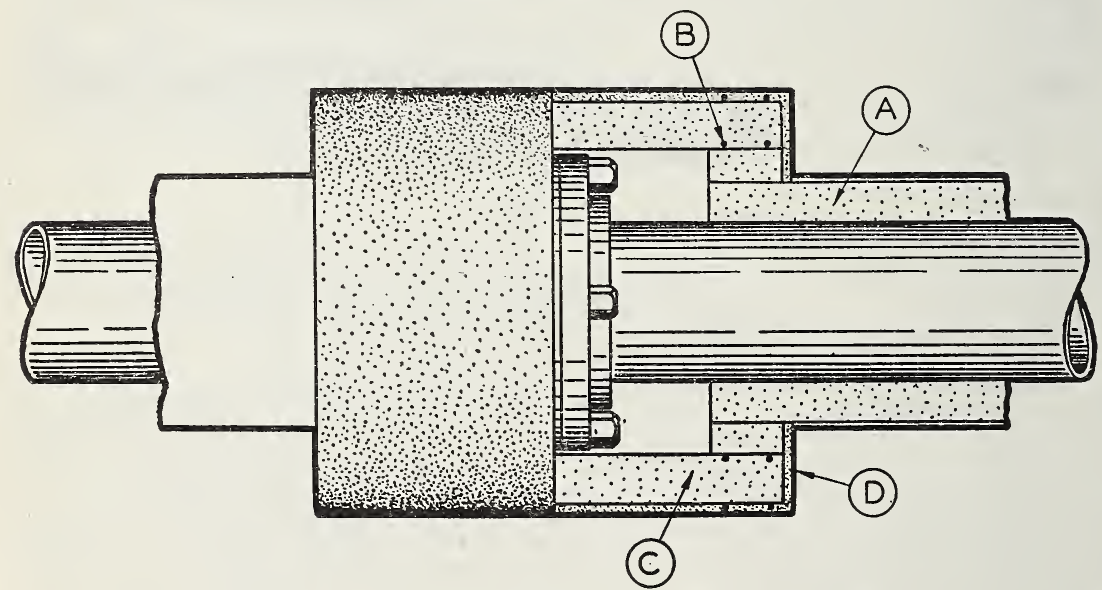

Figure 17.-Application of molded-type mineral wool pipe insulation to flanges and fittings.

$A$. Sectional pipe insulation; $B$, No. 16-gage galvanized wires or galvanized bands; $C$, sectional or segmental pipe insulation; $D$, insulating cement or other specified finish.

tight and smoothly pasted down at all side and end laps. Factory bands shall be applied, one binding the adjacent ends and one at the center of each section. 
(2) When extra-weight canvas jacket is specified, the factoryweight canvas and bands (if furnished) shall be omitted. The pipe insulation shall be enclosed in 40-lb rosin-sized paper, over which the specified 6 - or 8-oz canvas jacket shall be sewed neatly in place with stitches spaced not more than $1 / 3$ in. apart, with seams located where least visible.

$33 \mathrm{~b}$. Insulation on flanges, valves, and fittings located indoors or not exposed to moisture or abrasion shall be covered with a 1/4-in. coat of insulating or finishing cement. Portland cement may be added to provide a harder finish.

(1) When specified, a 6- or 8-oz canvas jacket shall then be sewed or pasted neatly over the dry cement. Sewed canvas jackets on valves, flanges, and fittings shall be made continuous with the canvas on adjacent piping by overlapping or blind stitching.

34. Application of finish located outdoors.

34a. Molded-type pipe insulation and fittings located outdoors or exposed to moisture or abrasion shall be provided with a weatherproof protective finish in the same general manner as specified for blanket-type pipe insulation. (See paragraph 30b.)

\section{GUIDES FOR PAINTING}

35. When specified, insulation finishes shall be painted for identification purposes in accordance with "Scheme for the Identification of Piping Systems," issued by the American Standards Association (A13-1928).

36. The application of paint should be deferred until the insulated equipment has been operated at the design temperature for a sufficient length of time to thoroughly dry out all components of the installation.

37. When weatherproof finish of the emulsified-asphalt type is to be painted, it should be primed with at least one coat of aluminum paint before applying lead-in-oil paint. Asphalt-base paint may be used directly over the asphaltic finish when a black color is specified.

38. Canvas should be given at least one coat of glue size followed by two coats of lead-in-oil paint.

39. Galvanized metal is not ordinarily painted immediately following application. If painting is required, it should be done in accordance with manufacturers' directions.

40. Insulating cements and finishing cements ordinarily dry to a light color, and may be painted with a nonpenetrating paint such as aluminum.

\section{MAINTENANCE}

41. In order to maintain high thermal efficiency in conjunction with long insulation life, the following recommendations are made:

(a) Inspect all insulation jobs periodically, particularly those located outdoors or exposed to moisture, vibration, or abrasion.

(b) When equipment is moved, or if for other reasons the finish of the insulation is damaged or becomes loose, repair or replace as required to prevent deterioration. 
(c) For advice on problems in connection with any specific insulation application, consult the manufacturer or the contractor who applied it.

\section{GUARANTEE LABELS AND CERTIFICATES}

42. Manufacturers' labels.-In order that the purchaser may be assured of obtaining mineral wool insulation conforming to the requirements of this standard, it is recommended that products complying therewith bear a certificate, label, or imprint containing the following wording:

This mineral wool product is guaranteed to conform to the requirements of Commercial Standard CS117-44, as issued by the National Bureau of Standards, United States Department of Commerce.

(Name of Manufacturer)

43. The following is an illustration of the label adopted by the members of the Industrial Mineral Wool Institute to insure distributors and users of receiving mineral wool insulation that conforms to the requirements of this commercial standard.

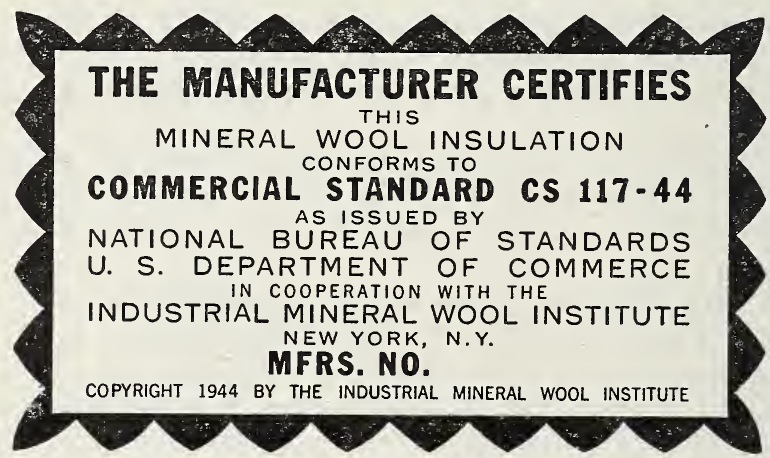

FIgURe 18.-Facsimile of Industrial Mineral Wool Institute label.

44. Installer's certificate--It is recommended that the installer or contractor furnish a certificate guaranteeing that the insulation is installed in strict accordance with this standard. The following wording is recommended for such certificate:

This has been insulated with (Type of equipment)

Class mineral wool installed in strict

compliance with the recommended installation requirements of Commercial Standard CS117-44, as issued by the National Bureau of Standards, United States Department of Commerce.

Date

(Signature) 


\section{Mineral Wool (High Temperature Installations)}

\section{EFFECTIVE DATE}

The standard is effective for new production from May 25, 1944.

\section{STANDING COMMITTEE}

The following individuals comprise the membership of the standing committee, which is to review, prior to circulation for acceptance, revisions proposed to keep the standard abreast of progress. Each organization nominated its own representatives. Comment concerning the standard and suggestions for revision may be addressed to any member of the committee or to the Division of Trade Standards, National Bureau of Standards, which acts as secretary for the committee.

E. V. Sanders (chairman), The Eagle-Picher Sales Co., American Bldg., Cincinnati 1, Ohio.

H. E. Lewrs, Owens-Corning Fiberglas Corporation, Nicholas Bldg., Toledo 1, Ohio.

D. H. Shearer, National Gypsum Co., Buffalo, N. Y.

K. M. RitchIe, Baldwin-Hill Co., 501 Klagg Ave., Trenton 2, N. J.

C. B. LyNDE, The Industrial Insulators, P. O. Box 2601, Houston, 1, Tex.

Frederick J. Heaslip, Fairbanks, Morse \& Co., 600 S. Michigan Ave., Chicago, IIl. (Representing National Association of Purchasing Agents).

HENRY E. AldRICH, American Boiler \& Affiliated Industries, 15 Park Row, New York 7, N. Y.

JoHN ReILLY, The Reilly-Benton Co., Inc., 613 Hibernia Bldg., New Orleans 12, La.

L. A. Foster, L. A. Foster Co., South Side`National Bank Bldg., 3606 Gravois Ave., St. Louis 16, Mo.

R. J. PотвURY, Bureau of Yards \& Docks, U. S. Navy Department, Washington $25, \mathrm{D} . \mathrm{C}$.

\section{HISTORY OF PROJECT}

On September 21, 1943, the Industrial Mineral Wool Institute requested the cooperation of the National Bureau of Standards in the establishment of a commercial standard for mineral wool: blankets, blocks, insulating cement, and pipe insulation for heated industrial equipment. A draft of the proposed commercial standard was submitted on November 1, 1943 to technical, distributor and consumer organizations, Government agencies, and to manufacturers for their review and comment.

On December 10, 1943, a meeting was held in Cleveland, Ohio, to review and consider all comments received. The standard was then adjusted in accordance with the composite recommendation of those concerned and circulated on January 7, 1944 to the trade for written acceptance.

Following acceptance by a satisfactory majority, in the absence of active opposition, announcement was issued on April 25, 1944, that the standard had been accepted as a recorded voluntary standard of the trade, effective for new production from May 25, 1944. 



\section{ACCEPTANCE OF COMMERCIAL STANDARD}

If acceptance has not previously been filed, this sheet properly filled in, signed and returned, will provide for the recording of your organization as an acceptor of this commercial standard.

Division of Trade Standards,

Date

National Bureau of Standards,

Washington 25, D. C.

Gentlemen:

Having considered the statements on the reverse side of this sheet, we accept the Commercial Standard CS117-44 as our standard of practice in the
Production ${ }^{1}$
Distribution $^{1}$
Use ${ }^{1}$
Testing ${ }^{1}$

of mineral wool: blankets, blocks, insulating cement, and pipe insulation for heated industrial equipment.

We will assist in securing its general recognition and use, and will cooperate with the standing committee to effect revisions of the standard when necessary.

Signature of individual officer

(In ink)

(Kindly typewrite or print the following lines)

Name and title of above officer

Organization

(Fill in exactly as it should be listed)

Street address

City and State

1 Please designate which group you represent by drawing lines through the other three. Please file separate acceptances for all subsidiary companies and affiliates which should be listed separately as acceptors. In the case of related interests, trade papers, colleges, etc., desiring to record their general approval, the words "in principle" should be added after the signature. 


\section{TO THE ACCEPTOR}

The following statements answer the usual questions arising in connection with the acceptance and its significance:

1. Enforcement.-Commercial standards are commodity specifications voluntarily established by mutual consent of those concerned. They present a common basis of understanding between the producer, distributor, and consumer and should not be confused with any plan of governmental regulation or control. The United States Department of Commerce has no regulatory power in the enforcement of their provisions, but since they represent the will of the interested groups as a whole, their provisions through usage soon become established as trade customs, and are made effective through incorporation into sales contracts by means of labels, invoices, and the like.

2. The acceptor's responsibility.-The purpose of commercial standards is to establish for specific commodities, nationally recognized grades or consumer criteria and the benefits therefrom will be measureable in direct proportion to their general recognition and actual use. Instances will occur when it may be necessary to deviate from the standard and the signing of an acceptance does not preclude such departures; however, such signature indicates an intention to follow the commercial standard where practicable, in the production, distribution, or consumption of the article in question.

3. The Department's responsibility.-The major function performed by the Department of Commerce in the voluntary establishment of commercial standards on a Nation-wide basis is fourfold: first, to act as an unbiased coordinator to bring all interested parties together for the mutually satisfactory adjustment of trade standards; second, to supply such assistance and advice as past experience with similar programs may suggest; third, to canvass and record the extent of acceptance and adherence to the standard on the part of producers, distributors, and users; and fourth, after acceptance, to publish and promulgate the standard for the information and guidance of buyers and sellers of the commodity.

4. Announcement and promulgation.-When the standard has been endorsed by a satisfactory majority of production or consumption in the absence of active, valid opposition, the success of the project is announced. If, however, in the opinion of the standing committee or the Department of Commerce, the support of any standard is inadequate, the right is reserved to withhold promulgation and publication. 
CS117-44

\section{ACCEPTORS}

The organizations and individuals listed below have accepted this specification as their standard of practice in the production, distribution and use of mineral wool. Such endorsement does not signify that they may not find it necessary to deviate from the standard, nor that producers so listed guarantee all of their products in this field to conform with the requirements of this standard. Therefore, specific evidence of conformity should be obtained where required.

\section{ASSOCIATIONS}

Construction Industries Association, New York' N. Y.

Dairymen's League Co-operative Association, Inc., New York, N. Y.

Industrial Mineral Wool Institute, New York, N. Y. National Cooperative Refinery Association, McPherson, Kans.

National District Heating Association, Pittsburgh, Pa.

National Slag Association, Washington, D. C. (In principle.)

North Dakota Mill \& Elevator Association, Grand Forks, N. Dak.

\section{FIRMS}

Adams, Franklin O., Tampa, Fla.

Air Preheater Corporation, Wellsville, N. Y.

Alcorn Combustion Co., Philadelphia, Pa.

Alexandria, City of, Power \& Light Department, Alexandria, La.

Allen, George W., La Porte, Ind.

Altfillisch, Charles, Decorah, Iowa.

American Agricultural Chemical Co., The, New York, N. Y.

American Crystal Sugar Co., Denver, Colo.

American Laundry Machinery Co., The Cincinnati, Ohio.

American Potash \& Chemical Corporation, Trona, Calif.

American Rock Wool Corporation, The, Chicago, IIl.

American Sugar Refining Co., The, New York, N.Y. American Thread Co., New York, N. Y.

Anaconda Copper Mining Co., Butte, Mont.

Asheim, Leonard, Bridgeport, Conn.

Ashland Oil \& Refining Co., Áshland, Ky.

Auchter Co., The George D., Jacksonville, Fla.

Austin, City of, Water, Light \& Power Department, Austin, Tex.

Baldwin-Hill Co., Trenton, N. J.

Bayou State Oil Çorporation, Hosston, La.

Beech-Nut Packing Co., Canajoharie, N. Y.

Belle Alkali Co., Belle, W. Va.

Belli, Edo J., Chicago, Ill.

Bellman, Gillett \& Richards, Toledo, Ohio.

Bendix Áviation Corporation, Philadelphia, Pa.

Berger, F. E. \& R. L. Kelley, Champaign, Ill.

Berkebile Bros., Johnstown, Pa.

Bethlehem Steel Co., Bethlehem, $\mathrm{Pa}$.

Beuttler, William, Sioux City, Iowa.

Bishop, Horatio W., La Mesa, Calif.

Blake, Edgar Ovet, Evanston, Ill.

Blatter, R. H., Washington, D. C.

Blithe, Wesley Lesher, Philadelphia, $\mathrm{Pa}$.

Boehm, George A., New York, N. Y.

Bogner, Harry, Milwaukee, Wis.

Boston Woven Hose \& Rubber Co., Boston, Mass.

Bowsman Washed Sand \& Gravel Ço., Troy, Ohio.

Brainerd, Harry B., New York, N. Y. (In principle.)

Breyer Ice Cream Co., Inc., Long Island City, N. Y.

Brown Co., Berlin, N. H.

Brown \& Bigelow, St. Paul, Minn.

Brunswick Balke Collender Co., Muskegon, Mich.

(In principle.)

Brust \& Brust, Milwaukee, Wis.

Buechner \& Orth, St. Paul, Minn. (In principle.)
Byers Co., A. M., Pittsburgh, Pa.

California Oregon Power Co., The, Medford, Oreg.

Camlet, J. Thomas, Passaic, N.J.

Cannon \& Mullen, Salt Lake City, Utah.

Carder, Macon O., Amarillo, Tex.

Carney Rockwool Co., Mankato, Minn.

Carver Engineering Co., George P., Boston, Mass. Carey Manufacturing Co., The Philip, Lockland, Cincinnati, Ohio.

Chapin, Rollin C., Minneapolis, Minn. (In principle.)

Chase Brass \& Copper Co., Inc., Waterbury, Conn. Christman Co., The, Lansing, Mich.

Cities Service Öil Co., New York, N. Y.

Coffeyville, City of, Municipal Power \& Light Department, Coffeyville, Kans.

Colorado Fuel \& Iron Corporation, The, Pueblo, Colo.

Colorado Insulating Co., Denver, Colo.

Colorado Springs, City of, Department of Utilities Colorado Springs, Colo.

Combined Locks Paper Co., Combined Locks, Wis. Combustion Engineering Co., Inc., New York, N. Y.

Conrad \& Cummings, Binghamton, N. Y.

Consolidated Chemical Industries, Inc., New England Division, Woburn, Mass.

Coolidge, Shepley, Bulfinch \& Abbott, Boston Mass.

Cooper Construction Co., Detroit, Mich.

Corn Products Refining Co., Chicago, Ill.

Corson, Inc., G. \& W. H., Plymouth Meeting, Pa.

Coxe Stoker En gineering Ċo., Hazleton, $\mathrm{Pa}$.

Cram \& Ferguson, Boston, Mass.

Crane Co., Chicago, IIl.

Crosbie, Inc., J. E., Tulsa, Okla.

Crossett Lumber Co., Crossett, Ark.

Crowell \& Lancaster, Bangor, Maine.

Dakota Public Service Co., Bismarck, N. Dak.

Dallas, City of, Water Department, Dallas, Tex.

Danville State Hospital, Danville, Pa.

Day \& Zimmerman, Inc., Philadelphia, $\mathrm{Pa}$

Dayton Power \& Light Co., Dayton, Ohio.

DeJarnette, Charles Wagner, Des Moines, Iowa.

Deere \& Co., Moline, Ill.

DeLongchamps \& O'Brien, Reno, Nev.

Detroit Edison Co., The, Detroit, Mich.

Detroit Sulphite Pulp \& Paper Co., Detroit, Mich.

Dickey Associates, C. W., Honolulu, Hawaii.

Dietel, George J., Buffalo, N. Y.

Donovan, John J., Berkeley, Calif.

Downingtown Paper Co., Downingtown, Pa.

Duke Power Co., Charlotte, N. C.

Dunlop Tire \& Rubber Co., Buffalo, N. Y.

Eagle Pencil Co., Inc., New York, N. Y.

Eagle-Picher Sales Co., The, Cincinnati, Ohio.

English, Harold T., Hutchinson, Kans.

Everett \& Associates, H. F. Allentown, $\mathrm{Pa}$

Fetzer \& Fetzer, Salt Lake City, Utah.

Finkl \& Sons Co., A., Chicago, ill.

Firestone Tre \& Rubber Co., The, Akron, Ohio.

Flambeau Paper Co., Park Falls, Wis.

Flannagan, Eric G., Henderson, N. C.

Ford Motor Co., Iron Mountain Plant, Iron Mountain, Mich.

Forty Eight Insulations, Inc., Aurora, III.

Foster Co., L. A., St. Louis, Mo.

Fry, Lynn W., Ann Arbor, Mich.

Fuel Economy Engineering Co., St. Paul, Minn. 
Gehron, William, New York, N. Y.

General Steel Castings Corporation, Granite City, Ill.

Gilbert Engineering Co., Statesville, N. C.

Globe Wernicke Co., The, Norwood, Ohio.

Grand Island, City of, Water \& Light Department, Grand Island, Nebr.

Great Western Sugar Co., The, Denver, Colo., and Scottsblufi, Nebr.

Greenwood Light \& Water Plant, Greenwood, Miss.

Gulf States Paper Corporation, Tuscaloosa, Ala.

Gypsum Lime \& Alabastine, Canada, Ltd., Toronto, Ontario, Canada.

H \& B American Machinery Co., Pawtucket, R. I.

Hannaford \& Sons, Samuel, Cincinnati, Ohio.

Hasness, Carlisle D., Harrisburg, Pa.

Helfensteller, Hirsch \& Watson, St. Louis, Mo.

Hentz, Adler \& Shutze, Atlanta, Ga.

Higgins, Charles H., New York, N. Y

Hodgdon \& Son, Charles, Chicago, Ill.

Hoener, P. John, St. Louis, Mo.

Holsman \& Holsman, Chicago, Ill.

Hooker Electrochemical Co., Niagara Falls, N. Y.

Hoover \& Co., North Canton, Ohio.

Hope, Frank L., Jr., San Diego, Calif.

Hubbard Milling Co., Mankato, Minn.

Industrial Insulators, The, Houston, Tex.

Inland Paper Board, Inc., Vcrsailles, Conn.

Inland Waterways Corporation, New Orleans, La.

Insulation Products, Ltd., Toronto, Ontario, Canada.

Interlaken Mills, Dye Works, Fiskeville, R. I.

International Milling Co., Minneapolis, Minn.

International Shoe Co., Machinery \& Power Department, St. Louis, M̉o.

Iowa-Nebraska Light \& Power Co., Lincoln, Nebr.

Ivey, Inc., Edwin J., Seattle, Wash.

Jamme, Bernard E., Summit, N. J. (In principle.)

Jersey Central Power \& Light Co., Asbury Park, N.J.

Johnson, Wallwork \& Dukehart, Portland, Oreg.

Jones \& Co., Inc., Paul, Baltimore, Md.

Jones \& Laughlin Stecl Corporation, Pittsburgh, $\mathrm{Pa}$

Kansas State College, Department of Architecture, Manhattan, Kans. (In principle.)

Karno-Smith Co., Trenton, N.J.

Keefer Associates, Inc., Carl J., Cincinnati, Ohio.

Keich \& O'Brien, Warren, Ohio.

Kelley, Frederic P., New York, N. Y.

Kinston, City of, Department of Public Utilities, Kinston, N. C.

Kyle, Herbert S., Charleston, W. Va. (In principle.)

Larrick, Thomas, Athens, Ohio.

Latenser \& Sons, John, Omaha, Nebr.

Law, Law, Potter \& Nystrom, Madison, Wis.

Lee, W. H., Philadelphia, Pa.

Lenning \& Co., Charles, Philadelphia, $\mathrm{Pa}$

Levine, Ernest, Highland Park, N. J.

Levy, Will, St. Louis, Mo.

Lincoln, City of, Water \& Light Department, Lincoln, Nebr.

Lockhart Power Co., Lockhart, S. C.

Loose-Wiles Biscuit Co., Kansas City, Mo.

Lovatt, Geo. I., \& George I., Jr., Philadelphia, Pa

Lucht, Harry, W. Englewood, N. J

Ludowici-Celadon Co., Chicago, Ill

MacDonald Construction Co., John, Newton, Mass.

Magma Copper Co., Superior, Ariz.

Magnola Petroleum Co., Beaumont, Tex.

Mann \& Co., Hutchinson, Kans.

Marathon Paper Mills Co., Rothschild, Wis.

Marshall, City of, Municipal Utilities, Marshall, Mo.

Materiales Aislantes, S. A., Monterrey, N. L. Mexico.

Mauran, Russell, Crowell \& Mullgardt, St. Louis, Mo.

Mead Corporation, Kingsport Division, Kingsport, Tenn.

Medusa Portland Cement Co., Toledo, Ohio.

Meyer Construction Co., Edw. H., Oshkosh, Wis.

Miller \& Yeager, Tert e Haute, Ind.

Milwaukee Solvay Coke Co., Milwaukee, Wis.

Mineral Insulation Co., Chicago Ridge, Iil.

Missouri Power \& Light Co., Moberly, Mo.

Mitchell \& Smith, Inc., Ohio Insulation Division, Toledo, Ohio.

Montana-Dakota Utilities Co., Minneapolis, Minn.

Mooser, William, San Francisco, Calif.

Morell, N. I.., Bethlehem, Pa.

Mosinee Paper Mills Co., Mosinee, Wis.
Mueller, Hair \& Hetterich, Hamilton, Ohio.

Muhlenberg Bros., Reading, $\mathrm{Pa}$.

National Biscuit Co., New York, N. Y.

National Cash Register Co., Dayton, Ohio.

National Gypsum Co., Buffalo, N. Y.

National Rock Wool Sales, Inc., Lagro, Ind.

National Tube Co., Lorain, Ohio.

Nazareth Cement Co., Nazareth, $\mathrm{Pa}$.

Nelson, Albert L., St. Louis, Mo.

North Carolina Pulp Co., Plymouth, N. C.

North Carolina State College, Raleigh, N. C.

North Western Public Service Co., Huron, S. Dak.

Ohio State University, The, Columbus, Ohio.

Oklahoma Portland Cement Co., Ada, Okla.

Oman \& Lilienthal, Chicago, III.

Oneida, Ltd., Oneida, N. Y.

Otter Tail Power Co., Fergus Falls, Minn.

Overbagh, H. Malcolm, Hollis, N. Y.

Owens-Corning Fiberglas Corporation, Toledo, Ohio

Pasadena, City of, Light \& Power Department, Pasadena, Calif.

Penick \& Ford Ltd, Inc., Cedar Rapids, Iowa.

Pennsylvania Industrial School, Huntington, Pa.

Pennsylvania Salt Manufacturing Co. of Washington, Tacoma, Wash.

Pepper, Geo. W., Jr., Philadelphia, Pa.

Pet Milk Co., St. Louis, Mo.

Pettibone Mullikin Corporation, Chicago, Ill.

Phelps \& Dewees \& Simmons, San Antonio, Tex.

Philadelphia, City of, Bureau of Water, Philadelphia, $\mathrm{Pa}$.

Phoenix Hosiery Co., Milwaukee, Wis.

Pierre \& Wright, Indianaolis, Ind.

Pillsbury Flour Mills Co., Minneapolis, Minn.

Pittsburgh Plate Glass Co., Columbia Chemical Division, Barberton, Ohio.

Platt \& Bro., F. P., New York, N. Y.

Pocahontas Tanning Co., Frank, Pocahontas County, W. Va.

Poe Co., The C. W., Cleveland, Ohio.

Port Huron Sulphite \& Paper Co, Port Huron, Mich.

Proudfoot Rawson-Brooks \& Borg, Des Moines. Iowa.

Public Service Co. of Colorado, Denver, Colo.

Rather, J. T., Jr., Houston, Tex.

Resnikoff, A braham, New York, N. Y

Revere Sugar Refinery, Charlestown, Mass.

Rhinelander Paper Co., Rhinelander, Wis.

Ritchie \& Associates, James H., Boston, Mass.

Riverton Lime \& Stone Co., Inc., Riverton, Va.

Robert \& Co., Inc., Atlanta, Ga.

Rock Flcece Co., El Paso, Tex.

Rock Wool Manufacturing Co., Memphis, Tenn.

Rosenblatt \& Hunt, Inc., Charleston, W. Va.

Russell \& Erwin Manufacturing Co., New Britain, Conn.

Saint Croix Paper Co., Woodland, Washington County, Maine.

Savannah Sugar Refining Corporation, Savannah, Ga.

Schaffieer, Joseph C., New Rochelle, N. Y.

Schenley Affiliates, Lawrenceburg, Ind.

Schulzke, William H., Moline, Ill.

Scott Paper Co., Chester, Pa.

Seattle, City of, Department of Lighting, Seattle, Wash.

Servel, Inc., Evansville, Ind.

Shaver, Chas. W., Salina, Kans.

Shikles \& Co., J. W., Kansas City, Mo.

Smith, Hinchman \& Grylls, Inc., Detroit, Mich

Smith \& Sons Carpet Co., Alexander, Yonkers, N.Y.

Sonneborn \& Sons, Inc., L., Daugherty Refinery, Petrolia, $\mathrm{Pa}$.

Sordoni Construction Co., Wilkes-Barre, $\mathrm{Pa}$.

South Carolina Power Co., Charleston, S. C.

Southern Advance Bag \& Paper Co., Hodge, La.

Southern Colorado Power Co., Pueblo, Colo.

Southwestern Gas \& Electric Co., Shreveport, La.

Southwestern Public Service Co., Plainview, Tex.

Spreckels Sugar Co., San Francisco, Calif.

Spun Rock Wools, Ltd., Thorold, Ontario, Canada.

Staley Manufacturing Co., A. E., Decatur, $\mathbf{n l}$.

Standard Brands, Inc., New York, N. Y.

Stetson Co., John B., Philadelphia, Pa.

Stoetzel, Ralph E., Chicago, Ill.

Sun Oil Co., Philadelphia, Pa.

Swift \& Co., Chicago, Ill.

Sylvania Industrial Corporation, Fredericksburg, Va. 
Tampa Electric Co., Tampa, Fla.

Taylor, Ellery K., Haddonfield, N. J.

Taylor, Edward Cray \& Ellis Wing, Los Angeles, Calif.

Temple, Seth J.-Arthur Temple, Davenport, Iowa.

Tennessee Products Corporation, Nashville, Tenn.

Texas Technological College, Department of Architecture \& Allied Arts, Lubbock, Tex. (In principle.)

Thermal Industries, Indio, Calif.

Thilmany Pulp \& Paper Co., Kaukauna, Wis.

Thomas, Arthur E., Dallas, Tex.

Thorne, Henry Calder, Ithaca, N. Y.

Tidmarsh Engineering Co., Tueson, Ariz.

Tobin Packing Co., The, Albany, N. Y.

Trinidad Electric Transmission Railway \& Gas Co., Trinidad, Colo.

Union Electric Co. of Missouri, Rivermines, Mo.

Union Sugar Co., Betteravia, Calif.

United Light \& Power Service Co., Davenport, Iowa.

United Refining Co., Warren, Pa.

United States Mineral Wool Co., Chicago, Ill.

United Rock Wool Co., Salt Lake City, Utah.

Virginian Railway Co., The, Princeton, W. Va.

Virginia, City of, Water \& Light Department, Virginia, Minn.

Voell, Richard F., Alexandria, Va.

Vogel, Willis A., Toledo, Ohio.

Walsh, Louis A., Waterbury, Conn.

Ware Shoals Manufacturing Ćo., Ware Shoals, S. C. Washington, City of, Municipal Electric \& Water Department, Washington, N. C.

Watervliet Paper Co., Watervliet, Mich.

Waukesha Lime \& Stone Co., Waukesha, Wis.

Welch, Carroll E., Huntington, N. Y.

Wenner \& Fink, Philadelphia, $\mathrm{Pa}$.

West, Albert E. (Formerly Harper \& West), Boston, Mass.

West Texas Utilities Co., A bilene, Tex.

Western Electric Co., Inc., New York, N. Y.
White Bros. Smelting Corporation, Philadelphia, $\mathrm{Pa}$.

White Engineering Corporation, The J. G., New York, N. Y.

Wight \& Wight, Kansas City, Mo.

Wigton-Abbott Corporation, Plainfield, N. J.

Willatsen, Andrew, Seattle, Wash.

Williams, Coile \& Pipino, Newport News, Va.

Willson, Fred F., Bozeman, Mont.

Willys-Overland Motors, Inc., Aircraft Division, Toledo, Ohio.

Wilmore Co., The, Mansfield, Mass.

Wilson, Adrian, Los Angeles, Calif.

Wilson, Town of, Utilities Department, Wilson, N. C.

Wischmeyer, Wm. F., St. Louis, Mo.

Wisconsin Power \& Light Co., Madison, Wis.

Wisconsin, University of, Central Heating Station, Madison, Wis.

Wolff \& Munier, Inc., New York, N. Y.

Woolsulate, Inc., Salt Lake City, Utah.

Wright \& Wright, Detroit, Mich.

Wyandotte Chemicals Corporation, Wyandotte, Mich.

Zimmerman, A. C., Pasadena, Calif.

U. S. GOVERNMENT

Department of Agriculture, Washington, D. C.

Capitol Power Plant, Washington, D. C.

Federal Works Agency, Public Buildings Administration, Washington, D. C.

Interior, Department of the, Office of Indian Affairs, Chicago, Ill.

Justice, Department of, Construction Division, Bureau of Prisons, Washington, D. C.

National Housing Agency, Federal Housing Administration, Washington, D. C.

Navy Department, Bureau of Yards \& Docks, Washington, D. C.

U. S. Penitentiary, Lewisburg, Pa.

War Department, Washington, D. C. 
